論文

\title{
鋳物用生型砂の混練所要動力に及ぼす引張強度と 引張破断エネルギの影響
}

\author{
寺下敬次 郎* 宮 南 啓* 木 村 照 雄**

\section{Effect of Tensile Strength and Tensile-Breakup Energy on Mulling Power Requirement of Green Mold Sands}

by

\author{
Keijiro Terashita, Kei Miyanami and Teruo Kimura \\ (Department of Chemical Engineering, University of Osaka Prefecture, Sakai)
}

It is extremely important to clarify the relationship between mulling power requirement and tensile-breakup energy for rational design and evaluation of the industrial mulling processes.

In the present study, both transient and steady state mulling power has been measured and tensile process curves have been obtained by using a green mold sand with a bentonite as a binder calcined at various temperatures in a vertical cylindrical mixer.

The results obtained are as follows:

The tensile-breakup energy, time required to complete the mulling process and mulling power requirement are influenced by the tensile strength of the binder used and its calcined temperature. The mulling power requirement can be evaluated in terms of the tensile-breakup energy. These findings of the tensile process tests can be applied to estimate the power requirement for the mulling process.

(Received Jan. 14, 1983)

キー・ワード : 混練, 生型砂, 混練所要動力, 引張強度, 引張破断ェネルギ

\section{1 緒言}

湿潤粉粒体の混練操作は化学工業をはじめ, 食品, 梥業㧍よび鋳物工業などに打いて広く用いられている. しかし，混練機の選定や設計あるいは操作の解析に必 要な混練所要動力括よび混練状態の評価に関する報告 は，極めて少いとい兄る．とくに混練所要動力と混練 物の引張破断エネルギの関係などを検討した研究は見 られない。

われわれは，すでに，混練物の引張強度や圧密特性 などから混練状態を評価できることを示すとともに， 湿潤粉粒体のかく汼抵抗に及涪す固液系の充て几特性 (ペンデュラー域, ファニキュラー域, キャピラリー 域）と引張強度の関係を調べた. 混練操作は主にペン デュラー域拉よびファニキュラー域を取り扱らが，そ の代表的な工業プロセスの一つとして鋳物用生型砂が ある、このプロセスに拉いては，生型砂が循環使用さ れているので，溶湯によって加熱された粘結剂を用い

†原稿受理 昭和58年 1 月 14 日

* 正 会 員 大阪府立大学工学部 堺市百舌鳥梅町

** 大阪府立大学工学部 堺市百舌鳥梅町
た場合, 生型砂の引張度や混練所要動力がぞのような 影響を受けるかを調べて括く必要がある.

そこで本研究では, 生型砂の混練（湿潤粉粒体の混 合）を粘結剂の焼成温度を種々変化させて行い，かく 拌抵抗を測定するとともに, 得られた生型砂の破断過 程曲線などを求めた．さらに，粘結剤の熱分析曲線捛 よび焼成ベントナイトや水一燒成ベントナイト系混練 物のX線回折図を検討した，その結果に基づいて，生 型砂の引張強度, 混練所要時間掞よび混練所要動力な ぞを求め，これらに及ぼす粘結剤の暁成温度の影響を 検討するとともに，引張破断に要するェネルギにより 混練所要動力を評価することを試みたので, 報告する.

\section{2 実験装置, 実験方法および粉粒体試料}

混練機として用いた垂直円筒型かく拌機とそのかく 找羽根形状を Fig. 1 に示した. かく汼槽は内径 140 $\mathrm{mm}$, 高さ $260 \mathrm{~mm}$ のメタアクリル製垂直円筒である. かく拌羽根は二段十字重ねであり，上側と下側の羽 根の迎光角はそれぞれ $60^{\circ}, 30^{\circ}$ である. さらに下側 の羽根は混練物をかき上げるように回転速度 $N=1 \mathrm{~s}^{-1}$ で回転させた。すなわち，上下羽根間に括ける圧延・ 


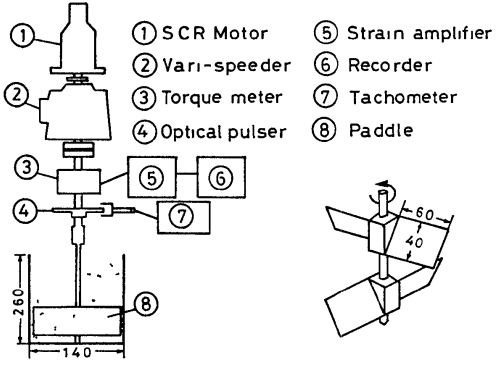

Fig. 1. Apparatus of vertical cylindrical mixer.

圧縮作用ならびに羽根回転によるせん断作用などによ り混練が促進される. かく拌羽根8は負荷変動に対し て一定回転速度を保つように制御された電動機(1)によ り駆動させた。また，かく拌抵抗はひずみゲージ式ト ルク変換器(3)（容量 : $5 \mathrm{~kg} ・ \mathrm{~m}$ ) により測定した.

ベントナイト（粘結剂）和よび生型砂（混練物）の 引張破断試験は，つり下げ式粉体層付着力測定機で行 った。 また，ベンナイトの焼成にはシリコニット坩堝 炉を用いた。常温から所定の温度まで約 3 時間で昇温 し, 焼成温度で 2 時間保ち, そののち外気により自然 放冷した.

試料砂の配合割合（重量基準）は, 生型砂の生産プ ロセスと同じである骨材（豪州産けい砂， $D_{50}=345$ $\mu \mathrm{m}) 100$, 粘結剤（米国産 $\mathrm{Na}$ 系ベントナイト） 7 , 二次粘結剤 (日本産石炭粉, $D_{50}=120 \mu \mathrm{m}$ ) 1.5 就よ び水 3 である.これらの混合・混練は，まずけい砂に ベントナイトを混合し，つぎに，この混合物に石炭粉 を添加混合して，最後に水を加えて混練した。な执， 得られる生型砂（混練物）の重量は $1.34 \mathrm{~kg}$ である.

\section{3 結果および考察}

\section{$3 \cdot 1$ 粘結剂の熱分析曲線および $\mathrm{X}$ 線回折図}

粘結剤であるベントナイトの熱分析曲線を Fig. 2 に示した，吸熱ピークは $126^{\circ} \mathrm{C}$ 近くで認め られ，この温度付近まで重量が著しく減少 していることから，吸着水が放出されてい

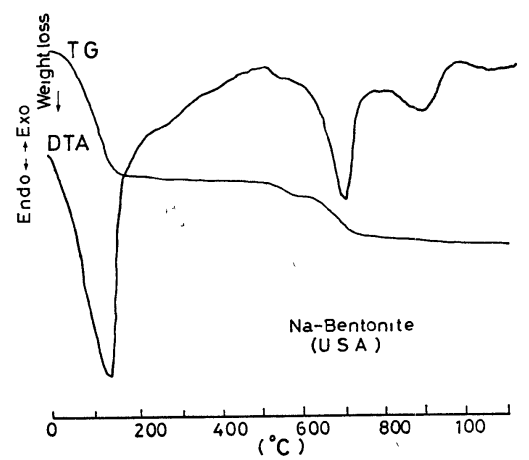

Fig. 2. TG-DTA curves of bentonite.

ることがわかる．また， $500{ }^{\circ} \mathrm{C}$ 付近より吸熱と重量の 減少が現れ， $692^{\circ} \mathrm{C} て ゙$ 吸熱ピークを示している.すな わら， $500^{\circ} \mathrm{C}$ 付近よりベントナイトの主成分粘土鉱物 であるモンモリロナイトの構造水 ( $\mathrm{OH}$ 基) の脱出が はじまり， $700^{\circ} \mathrm{C}$ 近くで大部分の脱水が終っている.

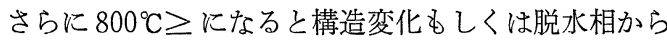
新しい結晶相へ移行するという吸熱および発熱ピーク が認められた。

Fig. 3 はシリコニット坩堝炉で焼成温度 $C_{T}$ を種々 変化させて得られたベントナイトのX線回折図の一例 を示したものである，焼成温度 $C_{T}$ が高くなるにつれ てモンモリロナイトの含有量は少くなっていることが わかる，すなわわ，ベントナイトの焼成温度が高くな ると粘結剂としての機能が劣化する傾向にあると考え られる。な拈，ベントナイトー水系の混練物のX線回 折図から，焼成温度 $C_{T} \geq 700^{\circ} \mathrm{C}$ になると水分子がモ ソモリロナイトの結晶層間に侵入しないことを確かめ ている.このことから，焼成温度 $\geq 700{ }^{\circ} \mathrm{C}$ にればモ ンモリロナイトの結晶構造に破壊が生じていることが わかる。

走査型電子顕微鏡で調ベた未焼成ベントナイトの一 次粒子は $2 \sim 5 \mu \mathrm{m}$ が ほとんどであった. しかし，焼 成温度 $C_{T}=550^{\circ} \mathrm{C}$ 付近になると焼結が起り，見掛け の粒径が 10〜25 $\mu \mathrm{m}$ のものが多くなった。 また， $C_{T}$ $\geq 700{ }^{\circ} \mathrm{C}$ の高温になると焼結がさらに進み，見掛けの 粒径が $30 \mu \mathrm{m}$ 以上のものも多くなっていることがわ かった。

$3 \cdot 2$ 生型砂の引張強度および引張破断エネルギ

Fig. 4 には焼成温度 $C_{T}$ を種々変化させて得られた ベントナイト（粘結剤）の引張強度 $\bar{\sigma}_{x, T}$ の一例を示 した. 引張強度 $\bar{\sigma}_{x, T}$ は焼成温度 $C_{T}$ が高くなるにつ れて減少し, $C_{T}=550^{\circ} \mathrm{C}$ 付近で最も小さい值を示して, 焼成温度が $800{ }^{\circ} \mathrm{C}$ になる $\bar{\sigma}_{x T}$ が逆に大きい值を示す といら興味ある結果が得られた。焼 成温度 $C_{T}=550^{\circ} \mathrm{C}$ 付近まで引張強度 が $C_{T}$ の増加とともに小さい值を示 すのは, 吸着水の放出によるごく微 小な水膜付着力の減少, 収着水の放 出する付近に和いてはモンモリロナ イトの含有量の減少と広い意味での 化学的な結合力の減少, さらに構造 水が脱出乙始めるとモンモリロナイ トに構造 (結合) 変化が生じること によるものと推察される。また, 焼 成温度 $C_{T}=800^{\circ} \mathrm{C}$ に执いて引張強 度 $\bar{\sigma}_{x, T}$ が大きい值を示しているの は，焼結により粒子間に固体架橋が 形成され，その結果付着 - 凝集力 


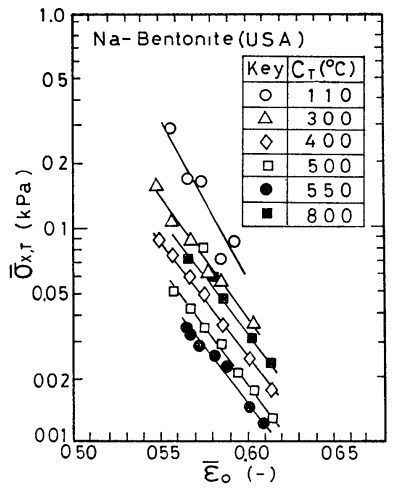

Fig. 4. Relationship between tensile strength $\bar{\sigma}_{x, T}$ and void fraction $\bar{\varepsilon}_{0}$ (Na-bentonite).

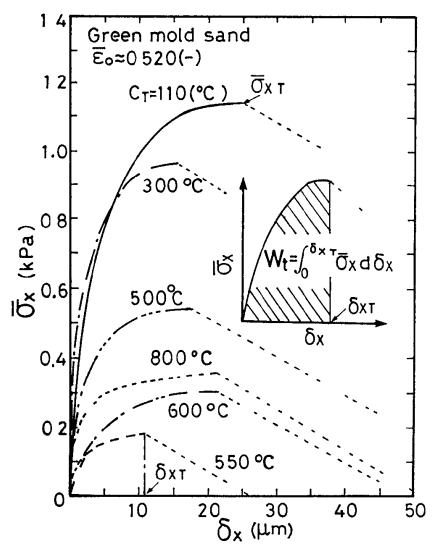

Fig. 5. Relationship between tensile stress $\bar{\sigma}_{x}$ and horizontal displacement $\delta_{x}$.

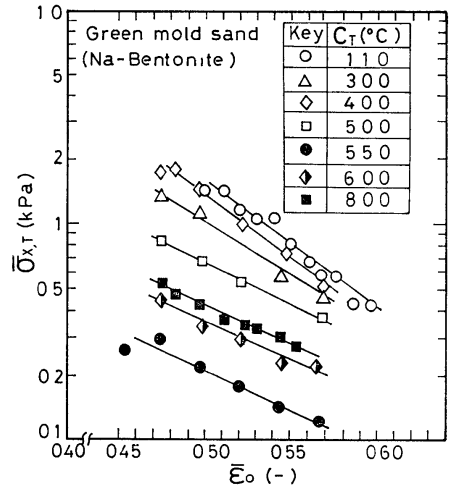

Fig. 6. Relationship between tensile strength $\bar{\sigma}_{x, T}$ and void fraction $\bar{\varepsilon}_{0}$ (green mold sand).
（焼結凝集）が増大することによるものと考えられる。 生型砂 (混練物) の引張破断過程曲線 (引張応力 $\bar{\sigma}_{x}$ 対水平変位 $\delta_{x}$ の関係）の一例を Fig. 5 に示した. ここでの生型砂は, 次節で述るよらに, かく拌抵抗が 定常值 $T_{s}$ を示したときに得られたものである. Fig. 5 からわかるように, 引張応力 $\bar{\sigma}_{x}$ が最大值 $\bar{\sigma}_{x, T}$ を 示す付近で生型砂が明りょらに破断し, その後 $\bar{\sigma}_{x}$ は 急激に減少している.ここでは, 引張応力 $\bar{\sigma}_{x}$ の最大 值を引張強度 $\bar{\sigma}_{x, T}$ とし，その值が得られる変位を破 断変位 $\delta_{x, T}$ と呼ぶことにした. 引張破断過程曲線を 模式的に表すと Fig. 5 中の図のようになる. そこで 図中の諸量に注目して, 以下の考察を行らことにする.

Fig. 6 は種々の焼成温度 $C_{T}$ におけるベントナイト を粘結剂として用いて得られた生型砂の引張強度 $\bar{\sigma}_{x, T}$ を示したものである. 生型砂の引張引度 $\bar{\sigma}_{x, T}$ は $C_{T}=$ $550^{\circ} \mathrm{C}$ で最も小さい值を示していることがわかる.こ の結果は, 焼成ベントナイトそのものの引張強度と同 じ傾向にあるといえる(Fig. 5 参照)。すなわち，生型 砂の引張強度の值には, 粘結剤であるベントナイトの $\bar{\sigma}_{x, T}$ が反映されている. したがって, ベントナイトの 引張強度を把握することは極めて重要である.

Fig. 7 には生型砂（混練物）の引張破断に要したエ ネルギ $W_{t}$ とベントナイトの焼成温度 $C_{T}$ の関係を示 した. 引張破断エネルギ $W_{t}$ の值は, 焼成温度 $C_{T}=$ $110 \sim 500^{\circ} \mathrm{C}$ をでは $C_{T}$ の増加とともに小さくなり, $C_{T}$ $=550^{\circ} \mathrm{C}$ で急激に減少し，それ以上の焼成温度になる と $W_{t}$ は逆に増大している. このょうに, 生型砂の引

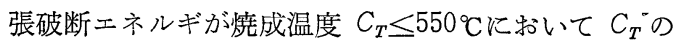
増加とともに小さい值を示すのは, 膨潤ベントナイト

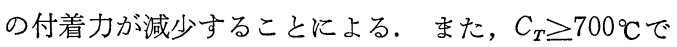
はモンモリロナイトの結晶層間に水和がほとんど起ら ないことから, 粒子間の水分量が増加する. その結果,

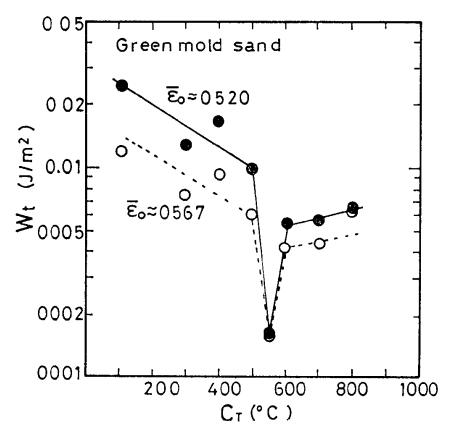

Fig. 7. Relationship between tensile-breakup energy $W_{t}$ and calcined temperature $C_{T}$.

液体架橋による水膜付着力の作用が増大し, $W_{t}$ が大 きい值を示したと考えられる. 以上の結果から, 生型 砂の引張破断エネルギは, ベントナイト粒子結晶片の 付着水や液体架橋の大小ならびにベントナイトそのも のの引張強度などの影響を受けていることがわかった。

\section{$3 \cdot 3$ 生型砂のかく䢁抵抗と混練所要時間}

焼成温度 $C_{T}$ をいろいろ変化させて得られた粘結剤 国 を用いて, 生型砂の混練過程に括けるかく找抵抗の時 間的変化を調べた結果の一例を Fig. 8 に示した. 同 図に拈いては，けい砂（骨材），ベントナイトおよび 石炭粉 (二次粘結剤) の混合過程に和けるかく汼抵抗 の時間的変化を省略してある. Fig. 8 からわかるよら に, 焼成温度 $C_{T}=110^{\circ} \mathrm{C}$ および $300^{\circ} \mathrm{C}$ のベントナイト を用いた生型砂のかく拌抵抗 $T$ は, 水が添加され混練 の進行にともない単調に増加したのち定常值 $T_{S}$ を示 している. これに対し， $C_{T} \geq 550^{\circ} \mathrm{C}$ を用いた生型砂の かく拌抵抗 $T$ は, 水の添加とともに急激に増大し, 短 時間で $T_{S}$ に到達していることがわかる.

かく汼抵抗が定常值 $T_{S}$ に到達すれば，混練が終了 していることを生型砂（混練物）の引張強度の測定值 あるいは走査型電子顕微鏡の観察結果より確かめてい 


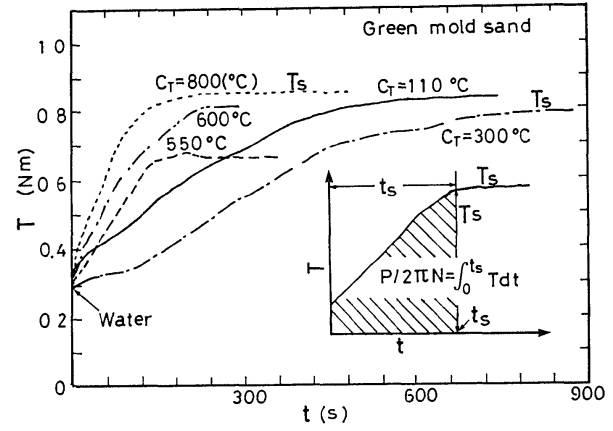

Fig. 8. Relationship between mixing torque $T$ and mixing time $t$.

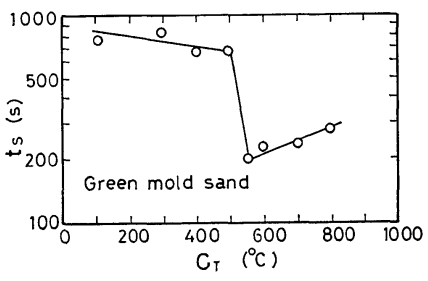

Fig. 9. Relationship between mulling time $t_{s}$ and calcined temperature $C_{T}$.

る. したがって， $T_{S}$ 亿到達する時間 $t_{S}$ (Fig. 8 参照) を求めることは混練操作に扣いて極めて重要である.

Fig. 9 には混練所要時間 $t_{s}$ に及ぼすべントナイトの 焼成温度 $C_{T}$ の影響を示した. $C_{T} \geq 550^{\circ} \mathrm{C}$ の粘結剤を 用いた生型砂の混練所要時間 $t_{S}$ は, $C_{T} \leq 500^{\circ} \mathrm{C}$ のも のに比べて短いことがわかる.すなわち，モンモリロ ナイトの構造水の脱水が始まる付近から結晶の層間に 水和の起らない粘結剤（ベントナイト）を用いた場合， 混練は早く進行するといえる.

\section{$3 \cdot 4$ 混練所要動力と引張破断エネルギの関係}

定常かく汼抵抗 $T$ に到達するまでの 混練所要動力 $P / 2 \pi N$ (Fig. 8 参照) をFig. 10 飞示した. 混練所 要動力の值は, 焼成温度 $500^{\circ} \mathrm{C}$ までは $C_{T}$ の増加につ れて小さくなり， $550^{\circ} \mathrm{C}$ 付近で急激に减少し，それ以 上の $C_{T}$ になると大きくなっていることがわかる．こ のような傾向は, 生型砂（混練物）の引張破断エネル ギ (Fig. 7) と同様である.

Fig. 11 は引張破断に要したェネルギ $W_{t}$ と混練所 要動力 $P / 2 \pi N$ の関係を示したものである. Fig. 11 からわかるように, 混練所要動力は引張破断に要した エネルギの増加とともに増大している，すなわち，生 型砂（湿潤粉粒体）の混練所要動力を引張破断エネル ギで評価できる。

\section{4 結言}

粘結剂の熱分析，焼成ベントナイトおよび 水一焼成 ベントナイト系混練物のX線回折より，粘結剤（ベン トナイト）の引張強度ならびに引張破断エネルギなど

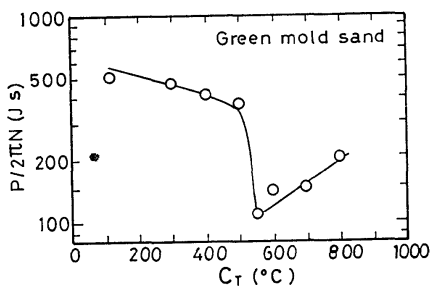

Fig. 10. Relationship between mulling power repuirement $P / 2 \pi N$ and calcined temperature $C_{T}$.

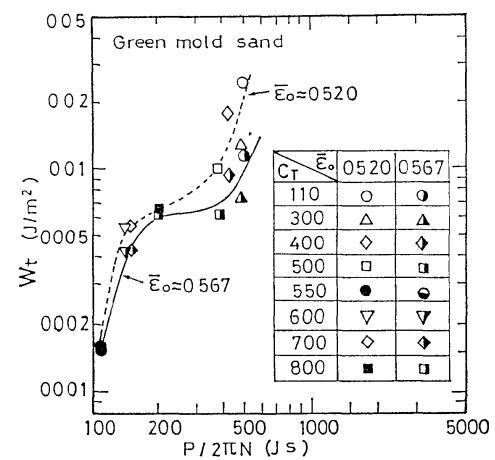

Fig. 11. Relationship between tensile-breakup energy $W_{t}$ and mulling power requirement $P / 2 \pi N$.

を考察した。

粘結剂の引張強度は, 焼成温度の 低い領域 $\left(C_{T} \leq\right.$ $550^{\circ} \mathrm{C}$ ) 亿抒いては水膜付着力の減少とモンモりロナイ トの構造変化により焼成温度の増大につれて小さい值 を示し，焼成温度の高い領域 $\left(C_{T} \geq 660^{\circ} \mathrm{C}\right)$ では粒子 の固体架橋などにより増大する。この粘結剂の引張強 度と焼成温度の関係は, 生型砂の引張強度や引張破断 エネルギの值に反映する. また，生型砂の結合機構は， 焼成温度の低い領域に执いては膨潤ベントナイトの付 着力, 高温領域では水膜付着力（液体架橋）であるこ とを示した，さらに，生型砂（湿潤粉粒体）の混練所 要動力を引張破断エネルギで評価できることを明らか にした。すなわち，混練プロセスへ引張破断試験結果 が応用できる。

最後に，本研究に対して，多大のご助言を賜った大 阪府立大工業技術研究所森正博主任研究員に深く感謝 の意を表す。

（昭和57年10月 7 日 第20回粉体汇関する討論会にて講嫔）

\section{参 考 文 献}

1）寺下敬次郎，宮南 啓，木村照雄，粉体工学会誌， 20, 9, 3 (1983).

2）寺下敬次郎, 宮南 啓, 小西孝信, 吉田純二, 材料, $\mathbf{3 0}$, 873 (1981).

3) 藤井謙治, 横山藤平, 粉体工学会誌, 16, 686 (1979).

4) 寺下敬次郎, 宮南 啓, 木村照雄, 塚口英世, 化学工学 協会第48年会にて発表, p.19（1983）京都 